\title{
Zeolite for Potential Toxic Metal Uptake from Contaminated Soil: A Brief Review
}

\author{
Claudia Belviso \\ National Research Council-Institute of Methodologies for Environmental Analysis-CNR, \\ 85050 Tito scalo (PZ), Italy; claudia.belviso@imaa.cnr.it; Tel.: +39-097-1427-224; Fax: +39-097-1427-222
}

Received: 1 June 2020; Accepted: 8 July 2020; Published: 11 July 2020

check for updates

\begin{abstract}
Soil pollution is an increasingly urgent problem for the global environment. Soil can be contaminated with potential toxic metals from many anthropogenic activities, besides fossil fuel combustion and crude oil production, ranging from industry to mining and agriculture. Many technologies have been analysed to solve this type of environmental pollution and methods involving the use of minerals (e.g., clay minerals, zeolites, and natural silica adsorbents) are widely described in the literature. This article provides a summary of studies concerning the use of zeolites in soil remediation. A considerable number of these experiments were conducted using natural zeolites, while fewer concerned the utilization of synthetic zeolites. The mechanism controlling the successful application of these minerals was analysed through referring to global data published on this topic over the last few decades. This review also briefly discusses the limitations on zeolite applications and the drawbacks of the approaches analysed.
\end{abstract}

Keywords: synthetic and natural zeolite; soil pollution; potential toxic metals

\section{Introduction}

Soil, commonly referred to as the upper layer of Earth's crust, is transformed by weathering and biological processes. It is composed of mineral particles, organic matter, water, living organisms, and air. However, mainly as a result of anthropogenic activities, soil can be characterized by the presence of high concentrations of different chemical elements responsible for "soil pollution".

Soil pollution is an alarming issue. The International Soil Reference and Information Centre (ISRIC) and the United Nations Environment Programme (UNEP), in 1990, already estimated that 22 million hectares of soil had been affected by soil pollution, and the data mainly referred to developed countries [1]. This problem has increased over the years. Rodríguez-Eugenio et al. [2] documented that $16 \%$ of all Chinese soils are categorized as polluted [3], 3 million potentially polluted sites were identified in the European Area and the West Balkans [4], 80,000 contaminated sites were estimated across Australia [5], and more than 1300 polluted areas are in the USA [6]. Moreover, the authors stressed the lack of data from low- and middle-income countries, thus highlighting what they consider as "one of the world's biggest global problems invisible to the international community" [2].

The main anthropogenic sources of soil pollution are represented by domestic and municipal waste, industrial activities, agriculture processes, military activities, mining, and petrol-derived products (Figure 1) [7-18], responsible for contamination by toxic metals, pesticides, and organic pollutants.

Along the others, potential toxic metals can pose long-term health risks to both ecosystems and human beings [19-24]. Some of these elements naturally occur at low concentrations in soils, and they are essential micronutrients for plants, but high amounts also have toxic effects, because metals are generally not degradable [25-29]. A well-known example is represented by $\mathrm{Cu}$, a heavy metal of both geogenic and anthropogenic origin. Kabata-Pendias [30] has indicated that its average concentration in soils is $20-30 \mathrm{mg} / \mathrm{kg}$; higher amounts due to pollution can affect plant growth and physiology [31,32]. 
However, natural sources and local geology can lead to higher values in many locations. Figure 2 shows the $\mathrm{Cu}$ concentration in European Union soil [33].

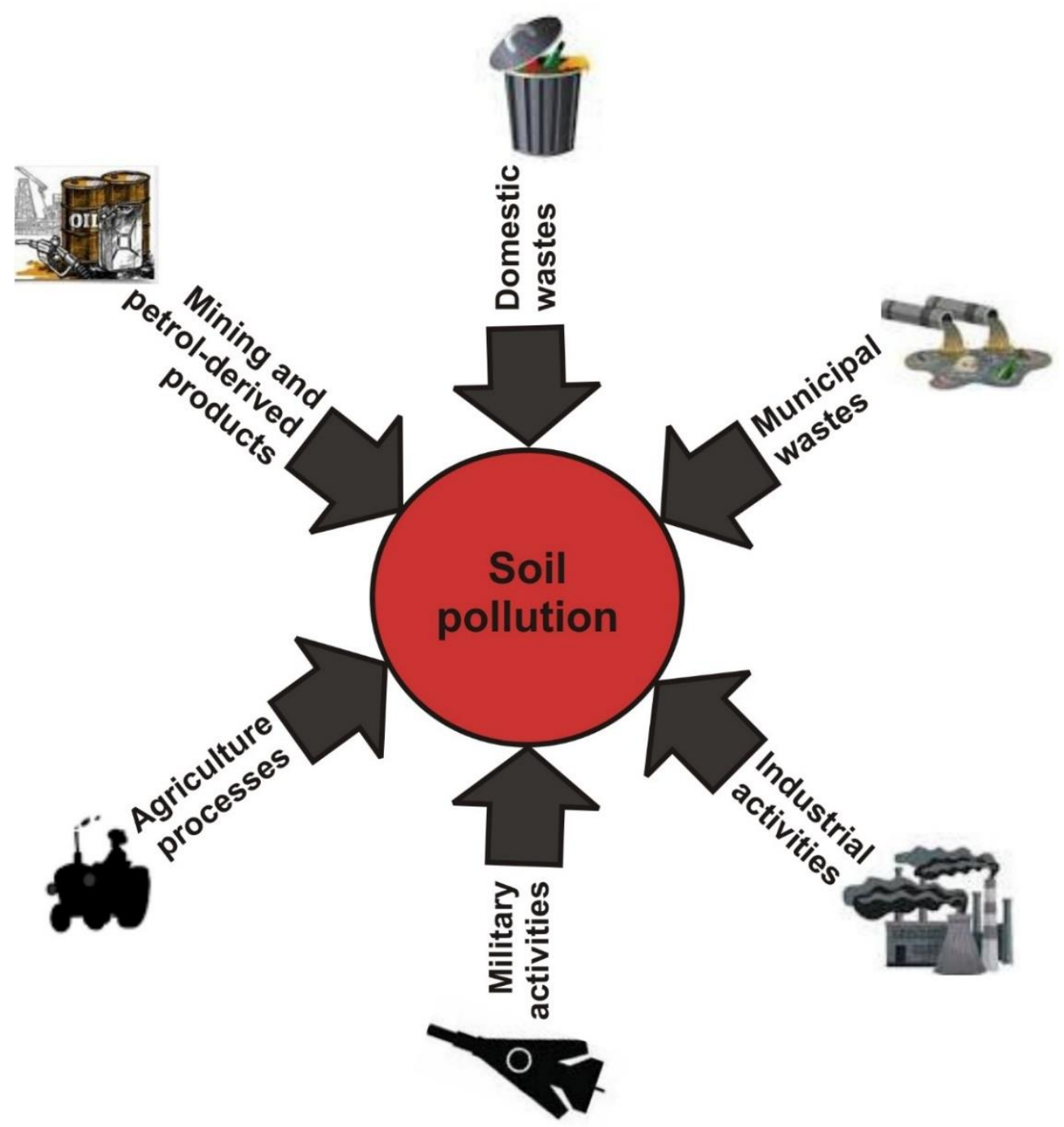

Figure 1. Main anthropogenic sources of soil pollution.

Potential toxic metals are in different geochemical forms that influence their mobility, bioavailability [34,35], and toxicity for human health. Several remediation technologies are based on heavy metal immobilization through processes of stabilization/solidification (S/S) [36]. "Stabilization" indicates that those techniques can convert contaminants into less a soluble or mobile form, thus reducing their toxicity; "solidification" refers to techniques encapsulating hazardous elements in materials or mineral structures of a high integrity. $S / S$ techniques include chemical processes (involving complex speciation reactions) and physical processes based on the sorption of an element on material surfaces or encapsulation in the matrix. Soil remediation by amendment with reactive minerals, such as carbonates, phosphate rocks, clay minerals, and zeolites, represents a stabilization/solidification technique reducing the bioavailability of toxic elements in many cases without dramatically altering natural soil function. Some minerals change $\mathrm{pH}$ soil conditions, thus determining the precipitation of insoluble phases with metals as major constituents [37-41]; others promote toxic element sorption on their surfaces [42-46] or heavy-metal encapsulation in their crystalline structure [47-50]. 


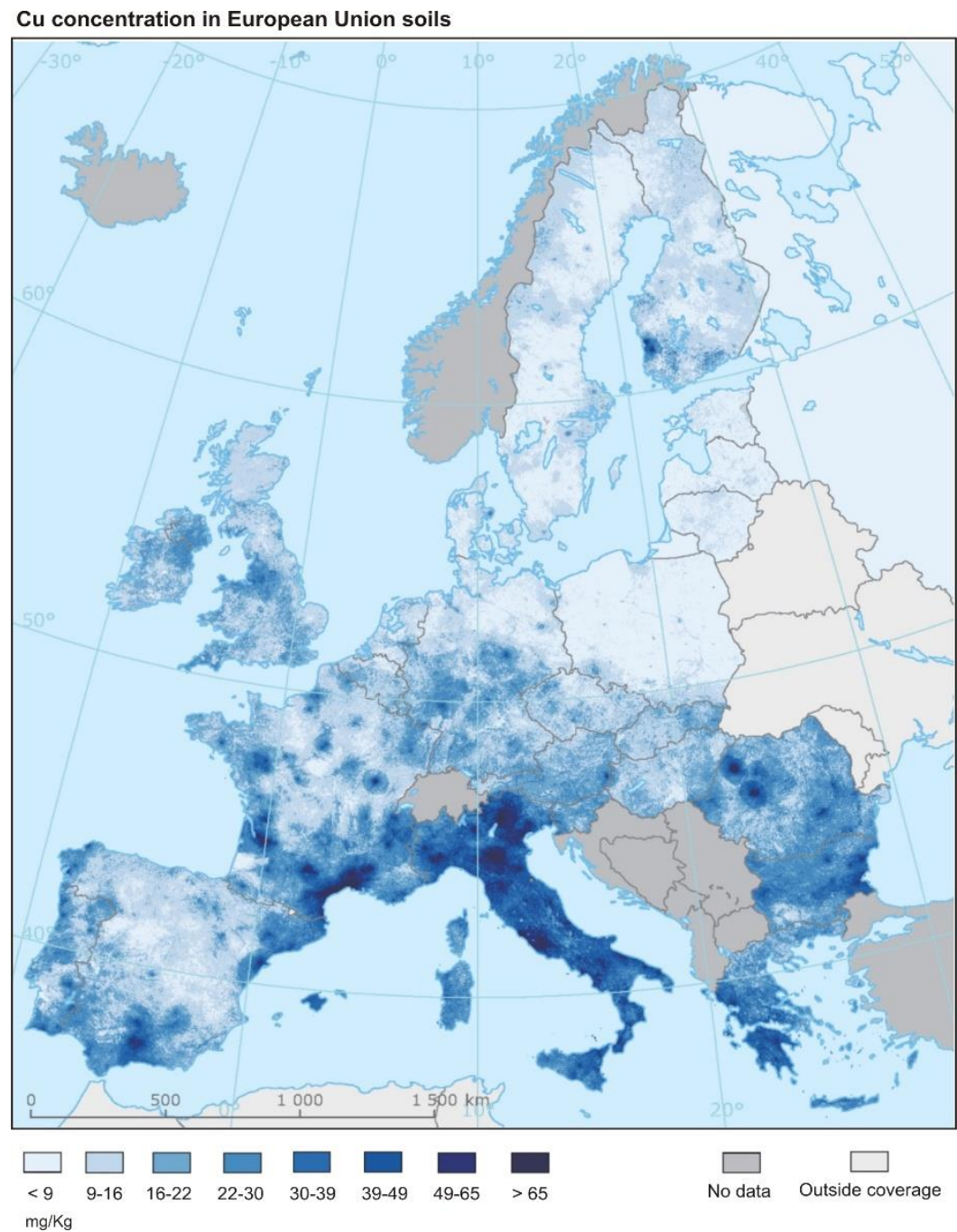

Figure 2. Copper concentration in European Union soils (adapted from [33]).

This study is focused on the use of natural and synthetic zeolites, and aims to summarize the current research on the use of these minerals for the remediation of heavy-metal polluted soil by stabilization/solidification processes. The advantages and limits on the application of these minerals are analysed and discussed.

\section{Natural and Synthetic Zeolite}

Zeolites are aluminosilicate (tectosilicate) with a three-dimensional network of $\mathrm{SiO}_{4}-\mathrm{AlO}_{4}$ tetrahedra, linked together by common oxygen atoms (Figure 3) [51]. Their general formula is $\mathrm{M}_{\mathrm{x}}{ }^{+} \mathrm{L}_{\mathrm{y}}{ }^{2+}\left[\mathrm{Al}_{(\mathrm{x}+2 \mathrm{y})} \mathrm{Si}_{1-(\mathrm{x}+2 \mathrm{y})} \mathrm{O}_{2 \mathrm{n}}\right] \cdot \mathrm{mH}_{2} \mathrm{O}$, where $\mathrm{M}^{+}$and $\mathrm{L}^{2+}$ indicate monovalent and divalent cations, respectively, placed together with water molecules within channels. The zeolite structure determines the high cation exchange capacity and the large surface areas that, together with thermal properties (temperature resistance, thermal stability and conductivity, and heat capacity), make these minerals very useful in many contexts, in addition to soil and water environmental remediation [52-58].

Figure 4 and Table 1 summarize the properties of the common natural and synthetic zeolites, respectively.

As a result of these properties, although natural zeolites are not as geologically abundant as other silicates, they have been studied more than other mineral groups, and many research activities have been developed to form synthetic products. 


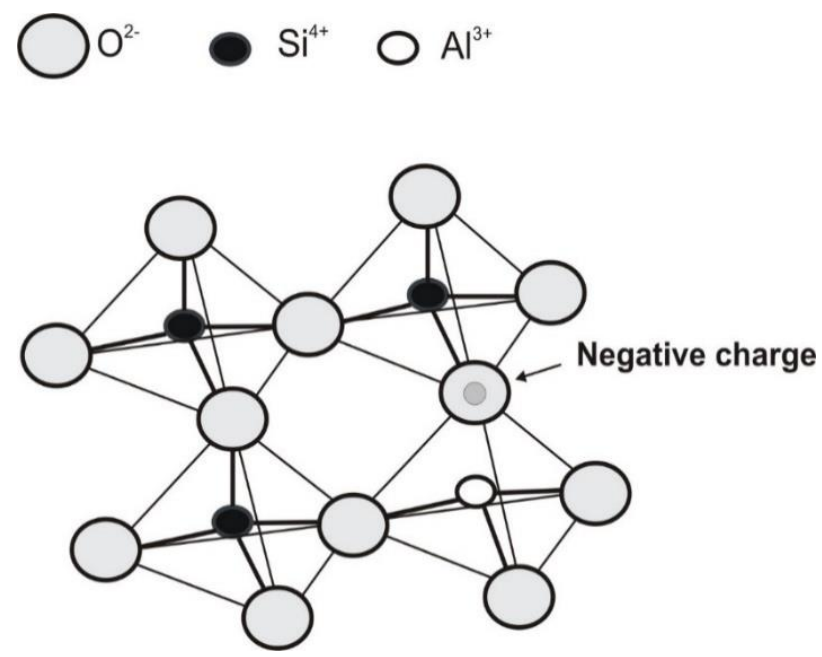

Figure 3. Zeolite framework of tetrahedral [SiO4]4- (adapted from $[59,60])$.

Table 1. Properties of some commonly available synthetic zeolite formed from fly ash.

\begin{tabular}{lcccc}
\hline & CEC & Channel/Pore Dimension & Void Volume & Specific Gravity \\
\cline { 2 - 5 } & $\mathbf{( m e q / g )}$ & $\mathbf{( \AA )}$ & $\mathbf{( \% )}$ & \\
\hline LTA & 4.7 & 4.1 & 47 & 1.99 \\
Faujasite & 1.41 & 7.4 & & 1.98 \\
Zeolite & 2.7 & $3.1 \times 4.5 / 2.8 \times 4.8$ & & \\
NaP & 0.3 & 2.3 & & $2.27-2.33$ \\
Sodalite & 0.3 & & \\
\hline
\end{tabular}

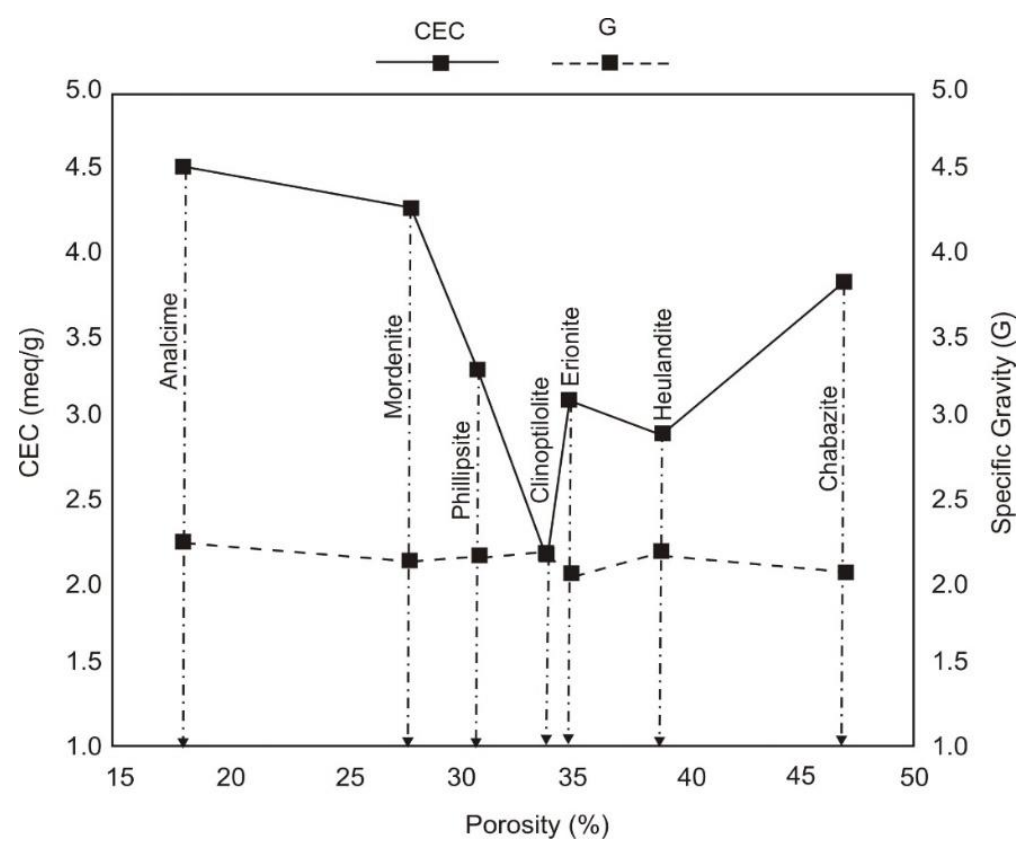

Figure 4. Cation exchange capacity (CEC) and specific gravity $(\mathrm{G})$ variation with porosity of most common natural zeolites (adapted from [61]).

Natural zeolite deposits are quite distributed in many parts of the world, and the genetic models for their formation range from weathering to low temperature hydrothermal systems and diagenesis in closed or open hydrologic systems, besides primary magnetic environments. These minerals occur as micro- and macro-scopic crystals in plutonic-rock fractures, metamorphic rocks, and mafic lava, or as 
submicroscopic crystals in glassy sediments submitted to diagenetic or low-metamorphic processes. The most common zeolite species are represented by chabazite, analcime, phillipsite, mordenite, and clinoptilolite-heulandite (Figure 5). According to the U.S. Geological Survey [62], the annual production of natural zeolites ranges from 1-1.3 million tons and it has remained essentially constant over the years.

[a]

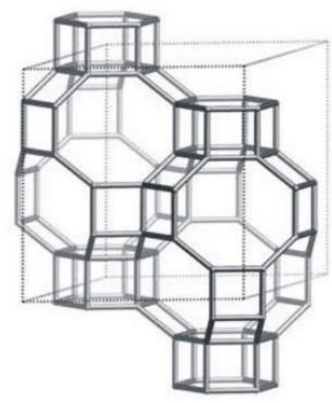

[c]

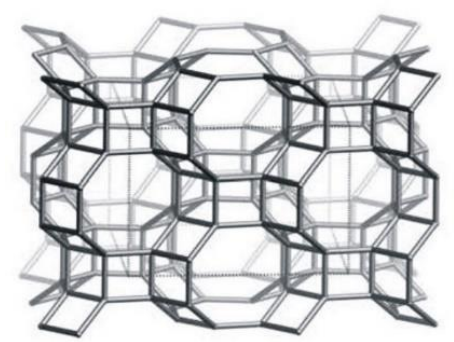

[b]

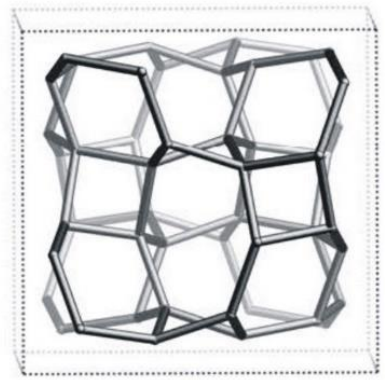

[d]

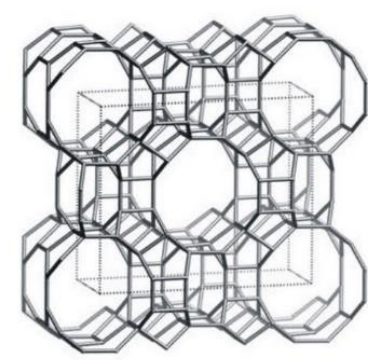

[e]

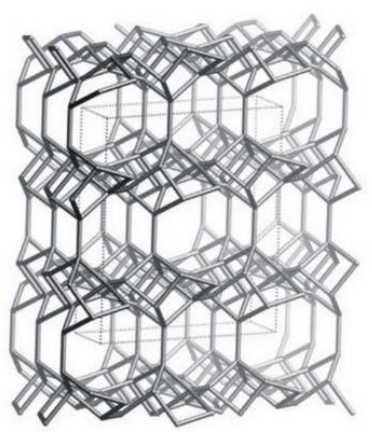

Figure 5. Structure of common natural zeolite frameworks viewed along [001]: (a) chabazite; (b) analcime; (c) phillipsite; (d) mordenite; and (e) clinoptilolite-heulandite. Modified from the Structure Commission of International Zeolite Association.

Literature data documented the formation of synthetic zeolites using several raw materials ranging from natural minerals [63-70] to waste materials [71-78] or pure silica and alumina sources [79,80]. Moreover, zeolites have been synthesised using different methods such as conventional and pre-fused hydrothermal processes [81-83], ultrasonic or microwaves methods [84-90] and multi-step technology [91,92]. The most commonly formed zeolites are zeolite A (LTA), faujasite, zeolite P and sodalite (Figure 6). In the last few decades, many researches have focused on the formation of nanozeolites showing advanced applications in many contexts such as medicine, catalysis, or the food industry [93-95].

In 2016, the consumption of synthetic zeolites was estimated at around 1.6 million tons [62]. 
[a]

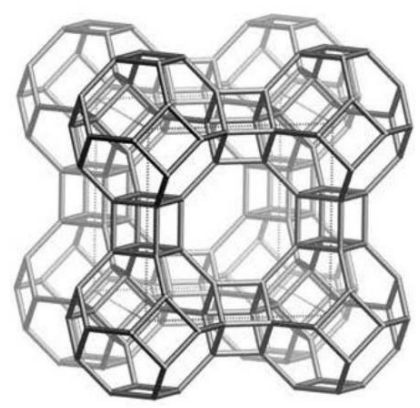

[c]

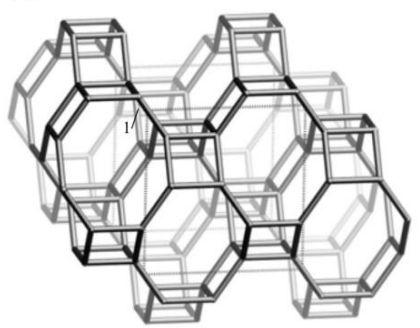

[b]

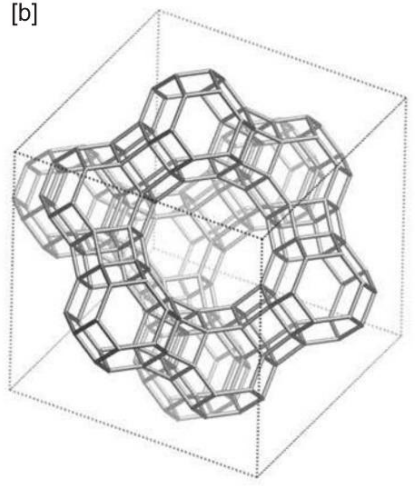

[d]

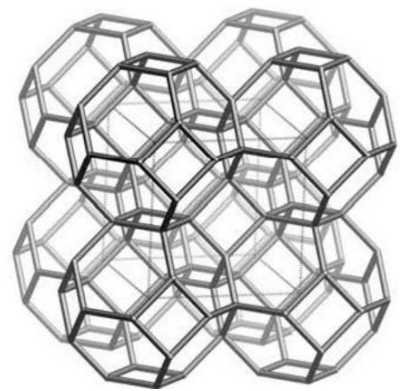

Figure 6. Structure of common synthetic zeolite frameworks. (a) Zeolite A (LTA: viewed along [001]); (b) faujasite (viewed along [110]); (c) zeolite P (viewed along [100]); and (d) sodalite (viewed along [001]). Modified from the Structure Commission of International Zeolite Association.

\section{Overview of Zeolite Use for Soil Remediation}

Many of the literature data have documented the large use of natural and synthetic zeolites for water remediation, whereas research on zeolite application to stabilize pollutants in the soil is still limited. Below, we discuss the application of different types of zeolites in toxic-metal soil remediation, exploring the advantages and limitations of the amendment process (Figure 7).

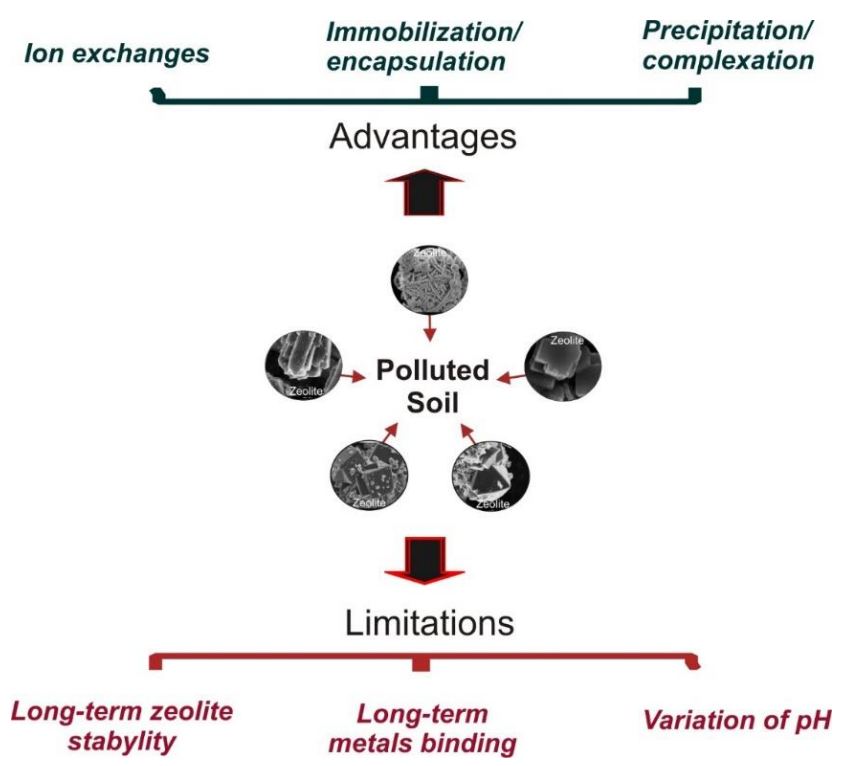

Figure 7. Zeolites and soil pollution: advantages and limitations. 


\subsection{Natural Zeolites and Soil Pollution}

The use of natural zeolites in soil remediation is mainly as a result of their singular properties. However, zeolites are natural material; thus, their use does not introduce additional pollution. This aspect, their easy availability in large amounts in different parts of the world, and their low cost, makes the application of these minerals very advantageous.

Natural zeolite has been used for heavy-metal remediation as a single additional phase to polluted soil or combined with other minerals (e.g., clay minerals) and processes (e.g., phytoremediation; Table 2).

Misaelides [96] published a short review on the application of natural zeolite to different types of environmental remediation, including the removal and/or stabilization of potential toxic metals in polluted soil. Regarding this specific type of contamination, the author referred to manuscripts on the application of natural and surfactant-modified zeolite or mixed treatments of zeolite and humic acids to stabilize $\mathrm{Cd}, \mathrm{Pb}$, or $\mathrm{Ni}$ in polluted soil $[97,98]$. The mechanisms controlling the successful use of natural zeolite were identified on the ion-exchange and adsorption processes, as well as on the surface precipitation/coprecipitation mechanism controlled by insoluble/soluble products interacting with additional minerals [99-102].

In detail, $\mathrm{Li}$ et al. [97] studied the effects of the addition of natural zeolite to artificially Pb-polluted garden soil. In their experiments, the authors used zeolite samples mainly consisting of clinoptilolite and heulandites. A sequential extraction process was performed to determine the lead availability after the addition of zeolites. The results indicated that the added minerals improved the chemical and physical properties of the soil, especially for the $\mathrm{pH}$ and cation-exchange capacity (CEC), thus restraining $\mathrm{Pb}$ uptake by plants. However, the increase in $\mathrm{pH}$ is considered to be the main mechanism controlling lead immobilization. The data also confirmed that the application of zeolite prevents organic-matter decrease, thus maintaining the soil structure. According to the authors, the appropriate zeolite dose to significantly reduce soluble lead is $\geq 10 \mathrm{~g} / \mathrm{kg}$.

Shi et al. [98] documented that the combined application of natural zeolite and humic acids leads to a greater reduction of $\mathrm{Pb}$ concentration in plants compared with that using a single zeolite. However, the data showed that the use of zeolite and humic acids reduces the available fraction of lead compounds, but slightly increases the $\mathrm{Pb}$ compound's water-soluble fraction. For these studies, the sequential extraction process was also crucial to achieve the results.

The positive action of the addition of natural zeolite on plant growth and toxic-metal $(\mathrm{Cd}, \mathrm{Ni}, \mathrm{Pb}$, and $\mathrm{Zn}$ ) availability in polluted soil was also analysed by Contin and co-workers [103]. The authors showed that the addition of zeolite to polluted soil significantly increased the biomass of the plant tissue due to the reduction of metal-toxicity stress, and to an improvement in plant nutrition. In detail, a decrease in the heavy-metal concentration in plant tissue was determined in the order of $\mathrm{Ni}>\mathrm{Cu}>$ $\mathrm{Cd}>\mathrm{Zn}$, while toxic-element leachability decreased as follows: $\mathrm{Cu}>\mathrm{Cd}>\mathrm{Ni}>\mathrm{Zn}$. These results were detectable already with $2.5 \% w / w$ of natural zeolites, but they were well-documented with the addition of $10 \%$. According to the authors, the $\mathrm{pH}$ increase due to zeolite addition had no determining effect on plant growth, whereas the addition of these minerals was responsible for both the alleviation of metal-toxicity stress and the improvement of soil fertility. Moreover, the data indicated that the presence of zeolites caused a general trend of reduction of all three transfer factors (roots/soil, shoots-roots, and shoots-soil). Regarding soil, the results showed that the addition of natural zeolites reduced toxic metal solubility due to the simultaneous occurrence of the effect of organic complexation and the three processes already described by Shi et al. [104], namely: pH rise, sorption by surface complexation, and cation-exchange retention. However, Shi et al. [104] explained that these three processes can be generalized in two parameters, $\mathrm{pH}$ value and cation exchange. The first is considered more important than the second.

Some literature data are not in accordance with the successful use of zeolite for the heavy-metal remediation of all types of polluted soil. Boros-Lajszner et al. [105] reported that the addition of zeolites (clinoptilolite) determines the reduction of $\mathrm{Ni}$ accumulation in oats $(11.69 \%)$ only grown in sandy silty 
loam, thus concluding that the efficiency of this mineral in nickel soil remediation is small. According to previous literature data [106], the authors attributed these results to the selectivity of clinoptilolite in absorbing heavy-metal ions $(\mathrm{Pb}>\mathrm{Cd}>\mathrm{Cs}>\mathrm{Cu}(\mathrm{II})>\mathrm{Co}(\mathrm{II})>\mathrm{Cr}(\mathrm{III})>\mathrm{Zn}>\mathrm{Ni}(\mathrm{II})>\mathrm{Hg}(\mathrm{II})$ ). Moreover, the granulometric soil composition has a no negligible role.

The efficiency of natural zeolite in reducing metal transfer to the upper part of plants by stabilizing toxic metals in contaminated soils was also investigated in combination with the use of other minerals such as bentonite [107-110]. Hamidpour et al. [109] showed that $\mathrm{Cd}(\mathrm{II})$ and $\mathrm{Pb}(\mathrm{II})$ concentrations in plant growth on enriched bentonite sand soil are higher than those planted in the enriched zeolite sand culture, thus indicating that heavy metals adsorbed onto zeolite are less mobile and bio-available compared with clay minerals. This is due to the different desorption mechanisms involved in the two mineral phases. According to the literature data, the authors indicated that ion exchange and chemisorption represent the main adsorption mechanisms of $\mathrm{Pb}$ onto zeolite, whereas ion exchange is the main process controlling the adsorption of the toxic elements on bentonite. Regarding $\mathrm{Cd}$, the amounts of toxic elements desorbed from zeolite were lower compared to the determined values for bentonite. These data displayed the formation of $\mathrm{Cd}$ surface precipitation and/or encapsulation into the zeolite channels. This is in accordance with the data from Panuccio et al. [110], who investigated cadmium sorption in zeolite, vermiculite, and pumice. Their results showed that the toxic element was adsorbed on the zeolite surfaces, and more than $70 \%$ of $\mathrm{Cd}$ was in a non-exchangeable form.

Sun et al. [111] studied the effects of multi-mineral polluted soil amendment, concluding that the $\mathrm{Cd}$ uptake by grain, straw, and maize significantly decreased in mica and zeolite treatments. Radziemska and Mazur [112] analysed the effects of combined halloysite and natural zeolite in decreasing the $\mathrm{Cr}, \mathrm{Zn}, \mathrm{Pb}, \mathrm{Cu}$, and Ni concentrations in polluted soil. The results showed that the addition of natural zeolites reduces the $\mathrm{Ni}$ and $\mathrm{Cu}$ content by $13 \%$ and $19 \%$, respectively. Moreover, the presence of zeolites also decreases the average concentration of $\mathrm{Cr}$.

Mahabadi et al. [113] performed column and batch experiments with the aim to investigate the effects of zeolite (clinoptilolite) addition on Cd leaching according to the texture of the polluted soil. The results of the batch experiments indicated that the use of $15 \%$ zeolite reduced Cd leaching by $98 \%$, $97 \%, 91 \%$, and $93 \%$ in loam, loamy sand, clay, and sand textures, respectively. The column experiment showed that $9 \%$ zeolite is the optimal quantity for reducing $\mathrm{Cd}$ leaching in clay and sand, whereas $15 \%$ is optimal for loamy soil. Batch and column tests were also carried out by Moirou et al., [114] in order to investigate the efficiency of clinoptilolite in the $\mathrm{Cd}, \mathrm{Zn}$, and $\mathrm{Pb}$ stabilization of polluted soil. Zeolite efficiency was investigated by pot and column experiments using 0 to $25 \%$ of the added mineral. The results showed that zeolite addition majorly reduced $\mathrm{Pb}$ solubility, and this effect occurred up to $10 \%$ of the added zeolite. A higher quantity did not seem to improve this result, which was also confirmed for $\mathrm{Zn}$. The column experiments showed a Pb solubility reduction by 50 to $60 \%$ compared with the control column, thus confirming that $\mathrm{Pb}$ immobilization is due to ion exchange reactions.

The adsorption behaviour of zeolite in acidic Cu-polluted soil was investigated by Antoniadis and Damalidis [25]. The authors used clinoptilolite, with a cation-exchange capacity of $226 \mathrm{cmol}_{\mathrm{C}} \mathrm{kg}^{-1}$ as the availability-reduction method. Zeolite efficiency was tested alone or in combination with liming. The results indicated that after 100 days, zeolite alone reduced the $\mathrm{Cu}$-extractable levels by $56 \%$, and this value increased up to $72 \%$ in combination with liming. This behaviour was due to $\mathrm{Cu}$ "infusion" onto zeolite surfaces, thus retaining the toxic element.

Wyszkowski [115] studied the reduction of the effect of $\mathrm{Cu}$ contamination on the content of the total organic carbon, total nitrogen, magnesium, potassium, and the available form of phosphorus by adding organic compounds, bentonite or zeolite $(2 \%)$. Considering that $\mathrm{Cu}$ pollution increases the total nitrogen content, the potassium amount, and the available phosphorus, thus negatively affecting the soil properties, the results indicated that amendment with zeolites decreased the content of the total nitrogen $(48 \%)$, and reduced the amount of potassium, organic carbon, and available phosphorus by $11 \%-12 \%$. However, the mechanism controlling the process, and therefore the zeolite efficiency, was not explained by the authors. 
Lastly, Hasanabi et al. [116] analysed the effects of natural nano-zeolite, modified nano-zeolite, and nanoporous activated carbon on $\mathrm{Pb}$ and $\mathrm{Cd}$ concentration in polluted soil. The results demonstrated that the use of modified nano-zeolite reduced the shoot $\mathrm{Pb}$ and $\mathrm{Cd}$ content by 33.2\% and 46.7\%, respectively. The high adsorption efficiency of modified zeolite is due to increases in the specific surface area after treatment with nitric acid.

\section{Limitations}

In the previous paragraph, the numerous studies describing the advantages of using zeolites as amendment in polluted soils have been documented; however, there is limited information in the literature about the potential disadvantages of the long-term application of natural zeolites.

These are mainly represented by the long-term effects of zeolites on soil $\mathrm{pH}$, or by the possibility to release large amounts of elements such as sodium because of the exchange process. In addition, polluting metal binding with zeolite is not well studied; thus, the persistence of toxic-metal immobilization is not completely clear $[103,117]$. The general stability of added zeolites in soils is still a matter of concern. Climatic and environmental conditions and mineral-type and size play an important role in zeolite persistence in soil [103]. In many cases, specific tests and long-term evaluation are required to determine this. Moreover, the contradictory results displayed by many literature data [113,118-120] underline that there is wide variation in the cation exchange capacity of natural zeolites because of differing structural defects, nature cage structures, and the ability of ion-absorption [103].

Table 2. Type of amendments for metals remediation.

\begin{tabular}{ccc}
\hline Zeolites & Heavy Metals & References \\
\hline & $\mathrm{Cd}, \mathrm{Pb}, \mathrm{Ni}$ & {$[96]$} \\
& $\mathrm{Pb}$ & {$[97]$} \\
$\mathrm{Cd}, \mathrm{Ni}, \mathrm{Pb}, \mathrm{Zn}$ & {$[103]$} \\
Natural zeolites & $\mathrm{Ni}$ & {$[105]$} \\
& $\mathrm{Cd}, \mathrm{Pb}$ & {$[109,110,116]$} \\
& $\mathrm{Cd}, \mathrm{Zn}, \mathrm{Pb}, \mathrm{Cu}, \mathrm{Ni}$ & {$[111,113]$} \\
& $\mathrm{Cd}, \mathrm{Zn}, \mathrm{Pb}$ & {$[112]$} \\
$\mathrm{Cu}$ & {$[25,115]$} \\
\hline \multirow{5}{*}{ Synthetic zeolites } & $\mathrm{Ni}, \mathrm{Pb}$ & {$[47,48]$} \\
& $\mathrm{Cu}, \mathrm{Cd}$ & {$[121]$} \\
& $\mathrm{Cd}, \mathrm{Ni}, \mathrm{Cd}, \mathrm{Co}, \mathrm{Cu}$ & {$[43,123]$} \\
& $\mathrm{Cd}, \mathrm{Cu}, \mathrm{Pb}, \mathrm{Zn}$ & {$[124]$} \\
$\mathrm{Cd}, \mathrm{Zn}$ & {$[125]$} \\
\hline
\end{tabular}

\subsection{Synthetic Zeolites and Potential Toxic Metals Soil Remediation}

The literature data on synthetic-zeolite application for soil remediation are rather scarce.

Recently, there has been growing interest in the use of zeolites formed from waste materials to solve environmental pollution, according to the developing concept of regenerative economy (Table 2).

In our previous studies, zeolite was directly synthesised in $\mathrm{Ni}$ - or Pb-polluted soil amended with coal fly ash, a waste product from coal combustion in thermoelectric-power plants [47,48]. The results from both laboratory and bench-scale experiments showed the formation of X-type zeolite (Figure 6b) after one month, and the amount of the newly formed mineral increased during the entire incubation period (one year). The results indicated that the presence of toxic elements did not exert any influence on zeolite formation, which plays a leading role in the mechanism of toxic-element immobilization. The data, in fact, showed that the newly formed zeolite captures both $\mathrm{Ni}$ and $\mathrm{Pb}$ in its structure while forming, thus reducing the mobilization of toxic elements by a typical mechanism of stabilization/solidification. Only when the structure of the newly formed mineral is destroyed 
by aggressive chemical attacks are the toxic elements mobilized through the action of the different reagents, depending on the $\mathrm{Ni}$ or $\mathrm{Pb}$ speciation.

Terzano et al. [121] also used zeolites synthesized in artificially $\mathrm{Cu}$ - and $\mathrm{Cd}$-polluted soil amended with coal fly ash as the remediation technology. The authors explained that the direct synthesis of zeolites in soil has the advantage of trapping toxic metals inside the structure of newly formed zeolite as hydroxide/oxide precipitates, thus ensuring the stabilization of toxic elements.

Lin et al. [122] used previously formed zeolite from fly ash as amendment for soil remediation. The authors demonstrated that the addition of different amounts of these newly formed minerals inhibits $\mathrm{Cd}$ leaching in polluted soil. According to the authors, the higher $\mathrm{pH}$, determined by the addition of zeolites and the cation exchange capacity of synthetic minerals, is responsible for stabilizing $\mathrm{Cd}$ in polluted soil.

The immobilization of potential toxic metals using zeolite synthetized from fly ash was also shown by Querol et al. [43], improving on experiments already performed in their previous manuscript [123]. The results confirmed that after soil amendment with synthetic zeolite (NaP1 zeolite; Figure $6 \mathrm{c}$ ), the leaching of $\mathrm{Zn}, \mathrm{Ni}, \mathrm{Cd}, \mathrm{Co}$, and $\mathrm{Cu}$ was decreased. This was due to the moderate increase of $\mathrm{pH}$ soil (from 3.3 to 7.6 ) connected to the presence of zeolites. The authors also explained that zeolite addition controls metal-immobilization, favouring their adsorption onto clay surfaces (characterizing mineralogical soil composition) and/or metal hydroxides precipitation.

Three types of commercial synthetic zeolites (zeolites A, Y, and P; Figure 6a-c) were instead used as amendments in $\mathrm{Cd}-, \mathrm{Cu}-, \mathrm{Pb}-$, and $\mathrm{Zn}$-contaminated soils by Edward and co-workers [124], with the aim to investigate the mechanisms controlling the reduction of the labile-metal concentration. The results demonstrated that the addition of zeolites changed the metal-speciation within the soil, thus reducing the mobility and bioavailability of toxic elements. According to the authors, the remediation mechanism of zeolites in the reducing metal bioavailability was based on the combination of the ion-exchange properties of these minerals and their ability to increase soil $\mathrm{pH}$ for the precipitation of metals as oxides or metal carbonates. Oste et al. [125] also reported on the efficiency of commercial synthetic zeolite in heavy-metal immobilization in polluted soil. Zeolite A, faujasite-type, and zeolite P (Figure 6a-c), were tested to remove $\mathrm{Cd}$ and $\mathrm{Zn}$ in artificially polluted soil. The results indicated that synthetic A-type zeolite had a high capacity to bind toxic metals, and soil alkalinity, due to the addition of zeolites, also improved metal sorption. The authors also analysed the effect of zeolite on dissolved organic matter in soil.

\section{Limitations}

The potential disadvantages of synthetic zeolites, mainly those formed from waste materials, are as a result of their long-term stability in a complex system such as soil, as well as to the long-term stability of heavy-metal bonds with added minerals. Moreover, the leaching behaviour of potentially toxic elements derived from the use of coal fly ash is an additional limitation in the use of products synthesised from this raw material. However, in our previous paper, we investigated the role of zeolitized fly ash on the mobility of some trace elements, and the results showed that the zeolitization process reduces the hazards of fly ash by immobilizing potential toxic elements coming from raw waste material in the stable structure of the newly formed zeolite [126].

Lastly, as already described for natural zeolites, a restriction in the use of synthetic products is also represented by the long-term effects of these minerals on soil pH. Fly ash that is used to form zeolite is characterized by a very high $\mathrm{pH}$, and, as consequence, the zeolite formed from this waste can cause a sensible increase in soil alkalinity, thus having a potentially negative effect on both soiland plant-ecosystems.

\section{Conclusions}

We gave a brief overview of the literature data on natural and synthetic zeolites use for heavy-metal soil remediation. Toxic element immobilization by amendment with zeolites generally takes place via stabilization/solidification processes. The ion-exchange properties of these minerals and their ability 
to increase soil $\mathrm{pH}$ determine the precipitations of potential toxic metals as oxides, or as other forms that can also be encapsulated in the zeolite structure during their synthesis directly in polluted soil if amended with waste materials such as fly ash. However, remediation techniques based on the application of zeolites also have some disadvantages, mainly represented by long-term stability and $\mathrm{pH}$ effects on the soil of these minerals. Moreover, zeolite formed using waste could be characterized by the leaching behaviour of the toxic elements derived from the source material.

Funding: This research received no external funding.

Conflicts of Interest: The author declares no conflict of interest.

\section{References}

1. Oldeman, L.R. World Map on Status of Human-Induced Soil Degradation; UNEP: Nairobi, Kenya; ISRIC: Wageningen, The Netherlands, 1991.

2. Rodríguez-Eugenio, N.; McLaughlin, M.; Pennock, D. Soil Pollution: A Hidden Reality; FAO: Rome, Italy, 2018; pp. 1-142.

3. CCICED. Special Policy Study on Soil Pollution Management; China Council for International Cooperation on Environment and Development: Beijing, China, 2015.

4. EEA. Progress in Management of Contaminated Sites; European Environment Agency: København, Denmark, 2014.

5. DECA. Assessment Levels for Soil, Sediment and Water; No. 4; Department of Environment and Conservation: Canberra, Australia, 2010; p. 56.

6. US EPA. Protecting and Restoring Land: Making a Visible Difference in Communities: OSWER FY13 End of Year Accomplishments Report; US EPA: Washington, DC, USA, 2013; pp. 1-47.

7. Palansooriyaa, K.N.; Shaheen, S.M.; Chen, S.S.; Tsang, D.C.W.; Hashimoto, Y.; Hou, D.; Bolan, N.S.; Rinklebe, J.; Ok, Y.S. Soil amendments for immobilization of potentially toxic elements in contaminated soils: A critical review. Environ. Int. 2020, 134, 105046. [CrossRef] [PubMed]

8. Certini, G.; Scalenghe, R.; Woods, W.I. The impact of warfare on the soil environment. Earth Sci. Rev. 2013, 127, 1-15. [CrossRef]

9. Gupta, D.K.; Chatterjee, S.; Datta, S.; Veer, V.; Walther, C. Role of phosphate fertilizers in heavy metal uptake and detoxification of toxic metals. Chemosphere 2014, 108, 134-144. [CrossRef] [PubMed]

10. Sas, W.; Głuchowski, A.; Radziemska, M.; Dzięcioł, J.; Szymański, A. Environmental and geotechnical assessment of the steel slags as a material for road structure. Materials 2015, 8, 4857-4875. [CrossRef] [PubMed]

11. Tuovinen, H.; Pohjolainen, E.M.; Lempinen, J.; Vesterbacka, D.; Read, D.; Solatie, D.; Lehto, J. Behaviour of radionuclides during microbiallyinduced mining of nickel at Talvivaara, Eastern Finland. J. Environ. Radioact. 2016, 151, 105-113. [CrossRef] [PubMed]

12. Zhang, J.; Fan, S.; Yang, J.; Du, X.; Li, F.; Hou, H. Petroleum contamination of soil and water, and their effects on vegetables by statistically analyzing entire data set. Sci. Total Environ. 2014, 476-477, 258-265. [CrossRef]

13. Huang, S.S.; Liao, Q.L.; Hua, M.; Wu, X.M.; Bi, K.S.; Yan, C.Y.; Chen, B.; Zhang, X.Y. Survey of heavy metal pollution and assessment of agricultural soil in Yangzhong district, Jiansu Province, China. Chemosphere 2007, 67, 2148-2155. [CrossRef] [PubMed]

14. Wang, Q.; Dong, Y.; Cui, Y.; Liu, X. Instances of soil and crop heavy metal contamination in China. Soil Sediment Contam. 2001, 10, 497-510.

15. Li, Z.; Ma, Z.; Van Der Kuijp, T.J.; Yuan, Z.; Huang, L. A review of soil heavy metal pollution from mines in China: Pollution and health risk assessment. Sci. Total Environ. 2014, 468, 843-853. [CrossRef] [PubMed]

16. Rodríguez-Seijo, A.; Lago-Vila, M.; Arenas-Lago, D.; Andrade, M.L.; Vega, F.A. Pollution and risk assessment of potential hazardous elements in shooting range soils (NW Spain). Span. J. Soil Sci. 2016, 6, 107-122.

17. Yang, Q.; Li, Z.; Lu, X.; Duan, Q.; Huang, L.; Bi, J. A review of soil heavy metal pollution from industrial and agricultural regions in China: Pollution and risk assessment. Sci. Total Environ. 2018, 642, 690-700. [CrossRef] [PubMed]

18. Hatje, V.; Pedreira, R.M.A.; De Rezende, C.E.; Schettini, C.A.F.; De Souza, G.C.; Marin, D.C.; Hackspacher, P.C. The environmental impacts of one of the largest tailing dam failures worldwide. Sci. Rep. 2017, 7, 10706. [CrossRef] [PubMed] 
19. Alloway, B.J. Sources of Heavy Metals and Metalloids in Soils. In Heavy Metals in Soils: Trace Metals and Metalloids in Soils and Their Bioavailability; Alloway, B.J., Ed.; Springer: Dordrecht, The Netherlands, 2013; pp. 11-50.

20. WHO. Lead Poisoning and Health. 2018. Available online: http://www.who.int/en/news-room/fact-sheets/d etail/lead-poisoning-and-health (accessed on 10 July 2020).

21. Kim, N.S.; Ahn, J.; Lee, B.K.; Park, J.; Kim, Y. Environmental exposures to lead, mercury, and cadmium among South Korean teenagers (KNHANES 2010-2013): Body burden and risk factors. Environ. Res. 2017, 156, 468-482. [CrossRef] [PubMed]

22. Lanphear, B.P.; Hornung, R.; Khoury, J.; Yolton, K.; Baghurst, P.; Bellinger, D.C.; Canfield, R.L.; Dietrich, K.N.; Bornschein, R.; Greene, T.; et al. Low level environmental lead exposure and children's intellectual function: An international pooled analysis. Environ. Health Perspect. 2005, 113, 894-899. [CrossRef] [PubMed]

23. Nabulo, G.; Young, S.D.; Black, C.R. Assessing risk to human health from tropical leafy vegetables grown on contaminated urban soils. Sci. Total Environ. 2010, 408, 5338-5351. [CrossRef] [PubMed]

24. O'Connor, D.; Hou, D.; Ye, J.; Zhang, Y.; Ok, Y.S.; Song, Y.; Coulon, F.; Peng, T.; Tian, L. Lead-based paint remains a major public health concern: A critical review of global production, trade, use, exposure, health risk, and implications. Environ. Int. 2018, 121, 85-101. [CrossRef] [PubMed]

25. Antoniadis, V.; Damalidis, K. Copper Availability in an Acidic and Limed Zeolite-Amended Soil. Commun. Soil Sci. Plant Anal. 2014, 45, 881-886. [CrossRef]

26. Adriano, D.C.; Wenzel, W.W.; Vangronsveld, J.; Bolan, N.S. Role of assisted natural remediation in environmental cleanup. Geoderma 2004, 122, 121-142. [CrossRef]

27. Li, P.J.; Wang, X.; Allinson, G.; Li, X.J.; Xiong, X.Z. Risk assessment of heavy metals in soil previously irrigated with industrial wastewater in Shenyang, China. J. Hazard. Mater. 2009, 161, 516-521. [CrossRef]

28. Akmal, M.; Xu, J.; Li, Z.; Wang, H.; Yao, H. Effects of lead and cadmium nitrate on biomass and substrate utilization pattern of soil microbial communities. Chemosphere 2005, 60, 508-514.

29. Liu, W.; Yang, Y.S.; Li, P.J.; Zhou, Q.X.; Xie, L.J.; Han, Y.P. Affiliations expand Risk assessment of cadmium-contaminated soil on plant DNA damage using RAPD and physiological indices. J. Hazard. Mater. 2009, 161, 878-883. [CrossRef] [PubMed]

30. Kabata-Pendias, A. Trace Elements in Soils and Plants, 4th ed.; CRC Press: Boca Raton, FL, USA, 2011.

31. Yruela, I. Copper in plants. Braz. J. Plant Phys. 2005, 17, 145-156. [CrossRef]

32. Overesch, M.; Rinklebe, J.; Broll, G.; Neue, H.U. Metals and arsenic in soils and corresponding vegetation at Central Elbe river floodplains (Germany). Environ. Pollut. 2007, 145, 800-812. [CrossRef] [PubMed]

33. Available online: https://www.eea.europa.eu/data-and-maps (accessed on 10 July 2020).

34. Harrison, R.M. Chemical association of $\mathrm{Pb}, \mathrm{Cd}, \mathrm{Cu}, \mathrm{Zn}$ in street dusts and roadside soil. Environ. Sci. Technol. 1981, 15, 1378-1383. [CrossRef]

35. Xian, X. Effect of chemical forms of cadmium, zinc and lead in polluted soils on their uptake by cabbage plants. Plant Soil 1989, 113, 257-264. [CrossRef]

36. Conner, J.R.; Hoeffner, S.L. A Critical Review of Stabilization/Solidification Technology. Crit. Rev. Environ. Sci. Technol. 1998, 28, 397-462. [CrossRef]

37. Rinklebe, J.; Shaheen, S.M. Miscellaneous additives can enhance plant uptake and affect geochemical fractions of copper in a heavily polluted riparian grassland soil. Ecotoxicol. Environ. Saf. 2015, 119, 58-65. [CrossRef]

38. Chen, Z.S.; Lee, G.J.; Liu, J.C. The effects of chemical remediation treatments on the extractability and speciation of cadmium and lead in contaminated soils. Chemosphere 2000, 41, 235-242. [CrossRef]

39. Basta, N.T.; Gradwohl, R.; Snethen, K.L.; Schroder, J.L. Chemical immobilization of lead, zinc and cadmium in smelter-contaminated soils using biosolids and rock phosphate. J. Environ. Qual. 2001, 30, 1222-1230. [CrossRef]

40. Seaman, J.C.; Arey, J.S.; Bertsch, P.M. Immobilization of nickel and other metals in contaminated sediments by hydroxyapatite addition. J. Environ. Qual. 2001, 30, 460-469. [CrossRef]

41. Park, J.H.; Lamb, D.; Paneerselvam, P.; Choppala, G.; Bolan, N.; Chung, J.-W. Role of organic amendments on enhanced bioremediation of heavy metal (loid) contaminated soils. J. Hazard. Mater. 2011, 185, 549-574. [CrossRef] [PubMed]

42. Bradl, H. Adsorption of heavy metal ions on clays. In Encyclopedia of Surface and Colloid Science; Somasundaran, P., Hubbard, A., Eds.; Taylor and Francis: New York, NY, USA, 2006; pp. 471-483. 
43. Querol, X.; Alastuey, A.; Moreno, N.; Alvarez-Ayuso, E.; Garcia-Sanchez, A.; Cama, J.; Ayora, C.; Simon, M. Immobilization of heavy metals in polluted soils by the addition of zeolitic material synthesized from coal fly ash. Chemosphere 2006, 62, 171-180. [CrossRef] [PubMed]

44. Cao, F.; Lian, C.; Yu, J.; Yang, H.; Lin, S. Study on the adsorption performance and competitive mechanism for heavy metal contaminants removal using novel multipore activated carbons derived from recyclable long-root Eichhornia crassipes. Bioresour. Technol. 2019, 276, 211-218. [CrossRef] [PubMed]

45. Usman, A.R.; Kuzyakov, Y.; Lorenz, K.; Stahr, K. Remediation of a soil contaminated with heavy metals by immobilizing compounds. J. Plant Nutr. Soil Sci. 2006, 169, 205-212. [CrossRef]

46. Panuccio, M.R.; Crea, F.; Sorgona, A.; Cacco, G. Adsorption of nutrients and cadmium by different minerals: Experimental studies and modelling. J. Environ. Manag. 2008, 88, 890-898. [CrossRef] [PubMed]

47. Belviso, C.; Cavalcante, F.; Ragone, P.; Fiore, S. Immobilization of Ni by synthesising zeolite at low temperatures in a polluted soil. Chemosphere 2010, 78, 1172-1176. [CrossRef]

48. Belviso, C.; Cavalcante, F.; Ragone, P.; Fiore, S. Immobilization of $\mathrm{Zn}$ and $\mathrm{Pb}$ in polluted soil by in-situ crystallization zeolites from fly ash. Water Air Soil Pollut. 2012, 223, 5357-5364. [CrossRef]

49. Terzano, R.; Spagnuolo, M.; Medici, L.; Tateo, F.; Vekemans, B.; Janssens, K.; Ruggero, P. Spectroscopic investigation on the chemical forms of $\mathrm{Cu}$ during the synthesis of zeolite $\mathrm{X}$ at low temperature. Appl. Geochem. 2006, 21, 993-1005. [CrossRef]

50. Cao, X.; Ma, L.Q.; Chen, M.; Singh, S.P.; Harris, W.G. Impacts of phosphate amendments on lead biogeochemistry at a contaminated site. Environ. Sci. Technol. 2002, 36, 5296-5304. [CrossRef]

51. Breck, D.W. Zeolite molecular sieves: Structure. In Chemistry and Use; John Wiley and Sons: New York, NY, USA, 1974.

52. Andronikashvili, T.; Pagava, K.; Kurashvili, T.; Eprikashvili, L. Possibility of Application of Natural Zeolites for Medicinal Purposes. Bull. Georgian Natl. Acad. Sci. 2009, 3, 158-167.

53. Franus, M.; Wdowin, M.; Bandura, L.; Franus, W. Removal of environmental pollutions using zeolites from fly ash: A review. Fresenius Environ. Bull. 2015, 24, 854-866.

54. Gjylia, S.; Korpa, A.; Tabanelli, T.; Trettin, R.; Cavani, F.; Belviso, C. Higher conversion rate of phenol alkylation with diethylcarbonate by using synthetic fly ash-based zeolites. Microporous Mesoporous Mater. 2019, 284, 434-442. [CrossRef]

55. Trung, N.T.; Alemi, N.; Haido, J.H.; Shariati, M.; Baradaran, S.; Yousif, S.T. Reduction of cement consumption by producing smart green concretes with natural zeolites. Smart Struct. Syst. 2019, 24, 415-425.

56. Shen, J.H.; Wang, Y.S.; Lin, J.P.; Wu, S.H.; Horng, J.J. Improving the indoor air quality of respiratory type of medical facility by zeolite filtering. J. Air Waste Manag. Assoc. 2014, 64, 13-18. [CrossRef] [PubMed]

57. Yu, C.H.; Huang, C.H.; Tan, C.S. A review of $\mathrm{CO}_{2}$ capture by absorption and adsorption. Aerosol Air Qual. Res. 2012, 12, 745-769. [CrossRef]

58. Kalankesh, L.R.; Rodríguez-Couto, S.; Zazouli, M.A.; Shahamat, Y.D.; Dianati, R.A.; Arghiani, M. Synthesis and characterization of nanoparticles and composites as bactericides. J. Microbiol. Methods 2019, 167, 105736. [CrossRef]

59. Querol, X.; Moreno, N.; Umana, J.C.; Alastuey, A.; Hernandez, E.; Lopez-Soler, A.; Plana, F. Synthesis of zeolites from coal fly ash: An overview. Int. J. Coal Geol. 2002, 50, 413-423. [CrossRef]

60. Belviso, C. State-of-the-art applications of fly ash from coal and biomass: A focus on zeolite synthesis processes and issues. Prog. Energy Combust. Sci. 2018, 65, 109-135. [CrossRef]

61. Jha, B.; Singh, D.N. A review on synthesis, characterization and industrial applications of flyash zeolites. J. Mater. Educ. 2011, 33, 65-132.

62. U.S. Geological Survey. Mineral Commodity Summaries 2016; U.S. Geological Survey: Reston, VA, USA, 2017. Available online: https://www.usgs.gov/centers/nmic/zeolites-statistics-and-informationthedocument:s3us-west-2.amazonaws.com/prd-wret/assets/palladium/production/mineral-pubs/zeolites/myb1-2016-zeoli.pdf (accessed on 10 July 2020).

63. Belviso, C.; Cavalcante, F.; Niceforo, G.; Lettino, A. Sodalite, faujasite and A-type zeolite from 2:1dioctahedral and 2:1:1 trioctahedral clay minerals. A singular review of synthesis methods through laboratory trials at a low incubation temperature. Powder Technol. 2017, 320, 483-497. [CrossRef]

64. Ríos, C.A.; Williams, C.D.; Fullen, M.A. Nucleation and growth history of zeolite LTA synthesized from kaolinite by two differentmethods. Appl. Clay Sci. 2009, 42, 446-454. [CrossRef] 
65. Belviso, C.; Giannossa, L.G.; Huertas, F.J.; Lettino, A.; Mangone, A.; Fiore, S. Synthesis of zeolites at low temperatures in fly ash-kaolinite mixtures. Microporous Mesoporous Mater. 2015, 212, 35-47. [CrossRef]

66. Gualtieri, A.; Norby, P.; Artioli, G.; Hanson, J. Kinetics of formation of zeolite Na-A [LTA] from natural kaolinites. Phys. Chem. Miner. 1997, 24, 191-199. [CrossRef]

67. Belviso, C.; Cavalcante, F.; Lettino, A.; Fiore, S. A and X type zeolite synthesized from kaolinite at low temperature. Appl. Clay Sci. 2013, 80-81, 162-168. [CrossRef]

68. Liu, H.; Shen, T.; Li, T.; Yuan, P.; Shi, G.; Bao, X. Green synthesis of zeolites froma natural aluminosilicate mineral rectorite: Effects of thermal treatment temperature. Appl. Clay Sci. 2014, 90, 53-60. [CrossRef]

69. Musyoka, N.M.; Missengue, R.; Kusisakana, M.; Petrik, L.F. Conversion of South African clays into high quality zeolites. Appl. Clay Sci. 2014, 97-98, 182-186. [CrossRef]

70. Belviso, C. EMT-type zeolite synthesized from obsidian. Microporous Mesoporous Mater. 2016, 226, 325-330. [CrossRef]

71. Wajama, T.; Kuzawa, K.; Ishimoto, H.; Tamada, O.; Nishiyama, T. The synthesis of zeolite P, linde type A and hydroxysodalite zeolites from paper sludge ash at low temperature $\left(80^{\circ} \mathrm{C}\right)$ : Optimal ash-leaching conditions for zeolite synthesis. Am. Mineral. 2004, 89, 1694-1700. [CrossRef]

72. Belviso, C.; Piancastelli, A.; Sturini, M.; Belviso, S. Synthesis of composite zeolite-layered double hydroxides using ultrasonic neutralized red mud. Microporous Mesoporous Mater. 2020, 299, 110108. [CrossRef]

73. Belviso, C.; Cannas, C.; Pinna, N.; Cavalcante, F.; Lettino, A.; Lotti, P.; Gatta, G.D. Effect of red mud added to zeolite LTA synthesis: Where is Fe in the newly-formed material? Microporous Mesoporous Mater. 2020, 298, 1100583. [CrossRef]

74. Belviso, C.; Kharchenko, A.; Agostinelli, E.; Cavalcante, F.; Peddis, D.; Varvaro, G.; Yaacoub, N.; Mintova, S. Red mud as aluminium source for the synthesis of magnetic zeolite. Microporous Mesoporous Mater. 2018, 270, 24-29. [CrossRef]

75. Ng, E.-P.; Awala, H.; Tan, K.-H.; Adam, F.; Retoux, R.; Mintova, S. EMT-type zeolite nanocrystals synthesized from rice husk. Microporous Mesoporous Mater. 2015, 204, 204-209. [CrossRef]

76. Belviso, S.; Cavalcante, F.; Lettino, A.; Ragone, P.; Belviso, C. Fly ash as raw material for the synthesis of zeolite-encapsulated porphyrazine and metallo porphyrazine tetrapyrrolic macrocycles. Microporous Mesoporous Mater. 2016, 236, 228-234. [CrossRef]

77. Saada, M.A.; Soulard, M.; Patarin, R.C.; Regis, R.C. Synthesis of zeolite materials from asbestos wastes: An economical approach. Microporous Mesoporous Mater. 2009, 122, 275-282. [CrossRef]

78. Belviso, C.; Agostinelli, E.; Belviso, S.; Cavalcante, F.; Pascucci, S.; Peddis, D.; Varvaro, G.; Fiore, S. Synthesis of magnetic zeolite at low temperature using a waste material mixture: Fly ash and red mud. Microporous Mesoporous Mater. 2015, 202, 208-216. [CrossRef]

79. Mintova, S.; Valtchev, V. Effect of the silica source on the formation of nanosized silicalite-1: An in situ dynamic light scattering study. Microporous Mesoporous Mater. 2002, 55, 171-179. [CrossRef]

80. Belviso, C.; Lettino, A.; Cavalcante, F. Influence of synthesis method on LTA time-dependent stability. Molecules 2018, 23, 2122. [CrossRef]

81. Shigemoto, N.; Hayashi, H.; Miyaura, K. Selective formation of Na-X zeolite from coal fly ash by fusion with sodium hydroxide prior to hydrothermal reaction. J. Mater. Sci. 1993, 28, 4781-4786. [CrossRef]

82. Belviso, C.; Cavalcante, F.; Fiore, S. Synthesis of zeolite from Italian coal fly ash: Differences in crystallization temperature using seawater instead of distilled water. Waste Manag. 2010, 30, 839-847. [CrossRef]

83. Belviso, C.; Perchiazzi, N.; Cavalcante, F. Zeolite from fly ash: An investigation on metastable behaviour of the newly-formed minerals in a medium-high temperature range. Ind. Eng. Chem. Res. 2019, 58, 20472-20480. [CrossRef]

84. Belviso, C. Ultrasonic vs hydrothermal method: Different approaches to convert fly ash into zeolite. How they affect the stability of synthetic products over time. Ultrason. Sonochem. 2018, 43, 9-14. [CrossRef] [PubMed]

85. Belviso, C.; Cavalcante, F.; Fiore, S. Ultrasonic waves induce rapid zeolite synthesis in a seawater solution. Ultrason. Sonochem. 2013, 20, 32-36. [CrossRef] [PubMed]

86. Belviso, C.; Cavalcante, F.; Lettino, A.; Fiore, S. Effects of ultrasonic treatment on zeolite synthesized from coal fly ash. Ultrason. Sonochem. 2011, 18, 661-668. [CrossRef] [PubMed]

87. Song, H.; Wan, X.; Sun, X. Preparation of Agy zeolites using microwave irradiation and study on their adsorptive desulphurisation performance. Can. J. Chem. Eng. 2013, 91, 915-923. [CrossRef] 
88. Tompsett, G.A.; Conner, W.C.; Yngvesson, K.S. Microwave synthesis of nanoporous materials. ChemPhysChem 2006, 7, 296-319. [CrossRef] [PubMed]

89. Hu, Y.; Liu, C.; Zhang, Y.; Ren, N.; Tang, Y. Microwave-assisted hydrothermal synthesis of nanozeolites with controllable size. Microporous Mesoporous Mater. 2009, 119, 306-314. [CrossRef]

90. Bukhari, S.S.; Behin, J.; Kazemian, H.; Rohani, S. Conversion of coal fly ash to zeolite utilizing microwave and ultrasound energies: A review. Fuel 2015, 140, 250-266. [CrossRef]

91. Larlus, O.; Mintova, S.; Bein, T. Environmental syntheses of nanosized zeolites with high yield and monomodal particle size distribution. Microporous Mesoporous Mater. 2006, 96, 405-412. [CrossRef]

92. Song, W.; Grassian, V.H.; Larsen, S.C. High yield method for nanocrystalline zeolite synthesis. Chem. Commun. 2005, 2951-2953. [CrossRef]

93. Guo, H.; Zhao, L.; Martineau-Corcos, C.; Fayon, F.; Viger-Gravel, J.; Awala, H.; Boullay, P.; Grand, J.; Vicente, A.; Gilson, J.-P.; et al. Transformation of Discrete Amorphous Aluminosilicate Nanoparticles into Nanosized Zeolites. Adv. Mater. Interfaces 2020, 2000634. [CrossRef]

94. Awala, H.; Gilson, J.P.; Retoux, R.; Boullay, P.; Goupil, J.M.; Valtchev, V.; Mintova, S. Template-free nanosized faujasite-type zeolites. Nat. Mater. 2015, 14, 447-451. [CrossRef] [PubMed]

95. Ng, E.-P.; Chateigner, D.; Bein, T.; Valtchev, V.; Mintova, S. Capturing Ultrasmall EMT Zeolite from Template-Free Systems. Science 2012, 335, 70-73. [CrossRef] [PubMed]

96. Misaelides, P. Application of natural zeolites in environmental remediation: A short review. Microporous Mesoporous Mater. 2011, 144, 15-18. [CrossRef]

97. Li, H.; Shi, W.; Shao, H.; Shao, M. The remediation of the lead-polluted garden soil by natural zeolite. J. Hazard. Mater. 2009, 169, 1106-1111. [CrossRef] [PubMed]

98. Shi, W.; Shao, H.; Li, H.; Shao, M.; Du, S. Co-remediation of the lead-polluted garden soil by exogenous natural zeolite and humic acids. J. Hazard. Mater. 2009, 167, 136-140. [CrossRef] [PubMed]

99. Colella, C. Environmental applications of natural zeolitic materials based on their ion-exchange properties. In Application of Natural Microporous Materials in Environmental Technology; Misaelides, P., Macasek, F., Pinnavaia, T.J., Colella, C., Eds.; Kluwer, NATO Science Series (Applied Sciences); Springer: Dordrecht, The Netherlands, 1999; Volume E362, pp. 207-224.

100. Vaughan, D.J.; Patrick, A.D. Mineral Surfaces; Chapman and Hall: London, UK, 1995.

101. Castaldi, P.; Santona, L.; Cozza, C.; Giuliano, V.; Abbruzzese, C.; Nastro, V.; Melis, P. Thermal and spectroscopic studies of zeolites exchanged with metal cations. J. Mol. Struct. 2005, 734, 99-105. [CrossRef]

102. Mondales, K.D.; Carland, R.M.; Aplan, F.F. The comparative ion exchange capacities of natural sedimentary and synthetic zeolites. Miner. Eng. 1995, 8, 535-548. [CrossRef]

103. Contin, M.; Miho, L.; Pellegrini, E.; Gjoka, F.; Shkurta, E. Effects of natural zeolites on ryegrass growth and bioavailability of $\mathrm{Cd}, \mathrm{Ni}, \mathrm{Pb}$, and $\mathrm{Zn}$ in an Albanian contaminated soil. J. Soils Sediments 2019, 19, 4052-4062. [CrossRef]

104. Shi, W.; Shao, H.; Hua, L.; Shao, M.; Du, S. Progress in the remediation of hazardous heavy metal-polluted soils by natural zeolite. J. Hazard. Mater. 2009, 170, 1-6. [CrossRef]

105. Boros-Lajszner, E.; Wyszkowska, J.; Kucharski, J. Use of zeolite to neutralise nickel in a soil environment. Environ. Monit. Assess. 2018, 190, 54. [CrossRef]

106. Tomczak, E.T.; Kamiński, W.L. Application of genetic algorithms to determine heavy metal ions sorption dynamics on clinoptilolite bed. Chem. Process Eng. 2012, 33, 103-116. [CrossRef]

107. Argiri, A.; Ioannou, Z.; Dimirkou, A. Impact of new soil amendments on the uptake of lead by crops. Commun. Soil Sci. Plant Anal. 2013, 44, 566-573. [CrossRef]

108. Shanableh, A.; Kharabsheh, A. Stabilization of $\mathrm{Cd}, \mathrm{Ni}$ and $\mathrm{Pb}$ in soil using natural zeolite. J. Hazard. Mater. 1996, 45, 207-217. [CrossRef]

109. Hamidpour, M.; Afyuni, M.; Kalbasi, M.; Khoshgoftarmanes, A.H.; Inglezakis, V.J. Mobility and plant-availability of $\mathrm{Cd}(\mathrm{II})$ and $\mathrm{Pb}$ (II) adsorbed on zeolite and bentonite. Appl. Clay Sci. 2010, 48, 342-348. [CrossRef]

110. Panuccio, M.R.; Sorgona, A.; Rizzo, M.; Cacco, G. Cadmium adsorption on vermiculite, zeolite and pumice: Batch experimental studies. J. Environ. Manag. 2009, 90, 364-374. [CrossRef]

111. Sun, Y.; Wu, Q.-T.; Lee, C.C.C.; Li, B.; Long, X. Cadmium Sorption Characteristics of Soil Amendments and its Relationship with the Cadmium Uptake by Hyperaccumulator and Normal Plants in Amended Soils. Int. J. Phytoremediat. 2014, 16, 496-508. [CrossRef] 
112. Radziemska, M.; Mazur, Z. Content of selected heavy metals in Ni-contaminated soil following the application of halloysite and zeolite. J. Ecol. Eng. 2016, 17, 125-133. [CrossRef]

113. Mahabadi, A.A.; Hajabbasi, M.A.; Khademi, H.; Kazemian, H. Soil cadmium stabilization using an Iranian natural zeolite. Geoderma 2007, 137, 388-393. [CrossRef]

114. Moirou, A.; Xenidis, A.; Paspaliaris, I. Stabilization Pb, Zn, and Cd-contaminated soil by means of natural zeolite. Soil. Sediment Contam. 2001, 10, 251-267. [CrossRef]

115. Wyszkowski, M. Soil Contamination with Copper and its Effect on Selected Soil Properties after Applying Neutralizing Substance. Pol. J. Environ. Stud. 2019, 28, 2465-2471. [CrossRef]

116. Hasanabadi, T.; Lack, S.; Modhej, A.; Lavifazel, H.G.M.; Ardakani, M.R. Feasibility Study on Reducing Lead and Cadmium Absorption by Alfalfa (Medicago scutellata L.) in a Contaminated Soil Using Nano-Activated. Carbon and Natural Based Nano-Zeolite. Not. Bot. Horti Agrobot. Cluj Napoca 2019, 47, 1185-1193. [CrossRef]

117. Campbell, L.S.; Davies, B.E. Experimental investigation of plant uptake of caesium from soil mended with clinoptilolite and calcium carbonate. Plants Soil 1997, 189, 65-74. [CrossRef]

118. Yi, Y.; Wen, J.; Zeng, G.; Zhang, T.; Huang, F.; Qin, H.; Tian, S. A comparative study for the stabilisation of heavy metal contaminated sediment by limestone, $\mathrm{MnO}_{2}$ and natural zeolite. Environ. Sci. Pollut. Res. 2017, 24, 795-804. [CrossRef] [PubMed]

119. Chlopecka, A.; Adriano, D.C. Mimicked In-situ stabilization of metals in cropped soil: Bioavailability and chemical form of zinc. Environ. Sci. Technol. 1996, 30, 3294-3303. [CrossRef]

120. Mineyev, V.G.; Kochetavkin, A.V.; Van Bo, N. Use of natural zeolites to prevent heavy metal pollution of soils and plants. Sov. Soil Sci. 1990, 22, 72-79.

121. Terzano, R.; Spagnuolo, M.; Medici, L.; Dorriné, W.; Janssens, K.; Ruggiero, P. Microscopic single particle characterization of zeolites synthesized in a soil polluted by copper or cadmium and treated with coal fly ash. Appl. Clay Sci. 2007, 35, 128-138. [CrossRef]

122. Lin, C.-F.; Lo, S.-S.; Lin, H.-Y.; Lee, Y. Stabilization of cadmium contaminated soils using synthesized zeolite. J. Hazard. Mater. 1998, 60, 217-226. [CrossRef]

123. Garcì-Sanchez, A.; Alastuey, A.; Querol, X. Heavy metal adsorption by different minerals: Application to the remediation of polluted soils. Sci. Total Environ. 1999, 242, 179-188. [CrossRef]

124. Edward, R.; Rebedea, I.; Lepp, N.W.; Lovell, A.J. An investigation into the mechanism by which synthetic zeolites reduce labile metal concentrations in soils. Environ. Geochem. Health 1999, 21, 157-173. [CrossRef]

125. Oste, L.A.; Lexmond, T.M.; Van Riemsdijk, W.H. Metal Immobilization in Soils Using Synthetic Zeolites. J. Environ. Qual. 2002, 31, 813-821. [CrossRef]

126. Belviso, C.; Cavalcante, F.; Di Gennaro, S.; Palma, A.; Ragone, P.; Fiore, S. Mobility of trace elements in fly ash and in zeolitised coal fly ash. Fuel 2015, 144, 369-379. [CrossRef] 